\title{
NUMERICAL INVESTIGATION OF THE CORE ECCENTRICITY EFFECT ON WAVE PROPAGATION IN EMBEDDED WAVEGUIDE
}

\author{
Beata ZIMA, Rafal KĘDRA \\ Gdańsk University of Technology, Faculty of Civil and Environmental Engineering, \\ Department of Mechanics of Materials and Structures, Narutowicza 11/12, 80-233 Gdańsk, Poland, \\ e-mails: beazima@pg.edu.pl, rafkedra@pg.edu.pl \\ Abstract \\ The paper presents results of theoretical and numerical investigation of guided wave propagation in two- \\ layer bars with geometric imperfections in the form of eccentric location of steel core. Steel rod of diameter \\ equal to $1 \mathrm{~cm}$ embedded in composite mortar-type cover with external diameter equal to $5 \mathrm{~cm}$ has been taken \\ into consideration. Several different rods with variable size of eccentricity are analysed. Results for rods with \\ misalignment of the cover and the core are presented as dispersion curves which were calculated using SAFE \\ method (semi-analytical finite element) and compared with results obtained for perfect axisymmetric rod. \\ Moreover, numerical calculation for several cases of imperfect rods were conducted and results given in the \\ form of displacements and accelerations maps and time-domain signals.
}

Keywords: elastic wave propagation, nondestructive diagnostics, eccentricity, embedded waveguide

\section{ANALIZA NUMERYCZNA WPŁYWU MIMOŚRODU RDZENIA NA PROPAGACJĘ FALI W PRĘCIE OSADZONYM}

\section{Streszczenie}

Praca przedstawia wyniki analizy teoretycznej oraz numerycznej dotyczącej propagacji fal prowadzonych $\mathrm{w}$ prętach dwuwarstwowych $\mathrm{z}$ imperfekcjami geometrycznymi w postaci niecentrycznego położenia stalowego rdzenia. Pod uwagę wzięto pręt stalowy o średnicy $1 \mathrm{~cm}$ osadzony w warstwie materiału kompozytowego typu zaprawa o zewnętrznej średnicy równej $5 \mathrm{~cm}$. Przeanalizowano kilka różnych przypadków mimośrodowego położenia pręta. Wyniki zarówno dla pręta bez imperfekcji, jak i dla prętów, dla których rdzeń i otulina nie są położone współosiowo zostały przedstawione w postaci krzywych dyspersji uzyskanych za pomocą metody SAFE (semi-analytical finite element). Ponadto, przeprowadzone zostały obliczenia numeryczne, a wyniki przestawione zostały w postaci przemieszczeń i przyspieszeń wywołanych ruchem falowym oraz sygnałów czasowych.

Słowa kluczowe: propagacja fal sprężystych, nieniszcząca diagnostyka, mimośród, pręt osadzony

\section{INTRODUCTION}

In recent years interest in nondestructive methods of structures diagnosing has increased substantially. Noninvasive diagnostic methods allow for fast, low-cost monitoring of large areas of structure without compromising its integrity.

One of the most popular nondestructive approach is method based on guided wave propagation. Since elastic wave potential for diagnostic evaluation has been recognized in 1951 by Firestone and Ling [1], number of papers has been devoted to possible applications of guided waves in defects detection. The main advantage of nondestructive methods based on wave propagation is a possibility to detect and localize even small damages during single measurement. Wave propagation has been also successfully used in diagnostics several types of engineering and mechanical objects. However, because of insignificant reduction in signal amplitude during propagation, guided waves are particularly attractive diagnostic tool in the case of monitoring long objects like beams, rods, rails and pipes. Palacz et al. detected an additional mass of the rod [2]. Time reversal method and spectral element method in diagnostics of rodlike structures were used by Lucena and Dos Santos [3]. Tse and Wang [4] detected circumferential notches in pipes and investigated the influence of their depth on wave behaviour. The influence of pipe bends on wave propagation was analyzed by Sanderson et al. [5]. Corrosion damage in pipelines was detected by Lowe et al. [6]. Damage detection in rails using ultrasonic methods was considered by Zumpano and Meo [7]. Rail integrity was the topic of interest of Mariani et al. [8], who proposed high-speed, noncontact monitoring system based on wave propagation.

Special attention was also paid to wave propagation in embedded waveguides. Metal rods embedded in material characterized by different 
properties were research objects of many scientists. Theoretical works about guided waves in multilayered bars were published by Armenakas [9], Baltrukonis [10], Thurston [11] and many others. One of common example of embedded waveguide is steel rod covered with concrete or mortar. It is one of the most frequently used material for civil engineering applications. Concrete with various steel inserts like bars, wires, strings, cables and nets is used for construction of buildings, bridges, dams or silos and for this reason its effective diagnosis attracts interest of researchers and engineers. Diagnostics of embedded waveguides using guided wave propagation was considered by Pavlakovic [12]. He conducted numerically and analytically damage detection of the anchorages of tendons of post-tensioned bridges. Epoxy bonded rock bolts were objects of research of Beard et al. [13]. They analysed wave mode sensitivity to material and geometry changes. In [14] they investigated wave attenuation in embedded tendons. Zou and his team published a series of works on influence of quality of the grout forming outer cover [15], curing time [16], excitation frequency [17] and missing grout [18] on wave propagation in laboratory models of rock bolts. Zima and Rucka presented [19],[10] detailed description of wave propagation phenomenon in damaged multilayered rod and they proved that elastic waves can be used to detect debonding between steel rod and the cover.

In most reported works the investigated objects are considered as perfectly axisymmetric while real objects are associated with geometric imperfections. An embedded waveguide is usually located eccentrically. Meanwhile, the presence of geometric imperfections like deviation form axial symmetry may significantly affect on wave propagation signals and in consequence prevent correct results interpretation.

This work contains the results of theoretical and numerical investigation of wave propagation in embedded waveguide with geometric imperfections. The two-layer models with variable eccentricity of the steel rod were considered. The results are presented as dispersion curves which were calculated using software GUIGUW (Graphical User Interface for Guided Ultrasonic Waves) based on semi-analytical finite element method (SAFE). SAFE allows to track dispersion curves for arbitrary cross sections when analytical solution is unknown. Moreover, numerical calculations using finite element programme Abaqus/Explicit have been performed and the results are presented in the form of acceleration and displacements maps. The results obtained for perfect axisymmetric rod and rods with misalignment of the core and the cover are compared.

\section{MODEL OF THE COVERED BAR}

Geometry of the investigated two-layer bar models are presented in Fig. 1. The analysis concerns steel bar $(E=210 \mathrm{GPa} ; \nu=0.3$; $\rho=7850 \mathrm{~kg} / \mathrm{m}^{3}$ ) with dimeter equal to $1 \mathrm{~cm}$ embedded in mortar cover $(E=10 \mathrm{GPa} ; v=0.2$; $\left.\rho=2000 \mathrm{~kg} / \mathrm{m}^{3}\right)$. The external diameter of the $\operatorname{rod}$ equals to $5 \mathrm{~cm}$. The analysis included one perfectly axisymmetric bar and five bars with imperfect eccentric steel rod location. Damping effects were neglected. The exemplary mesh of two-layer model of rod without imperfections performed in GUIGUW is given in Fig. 2.

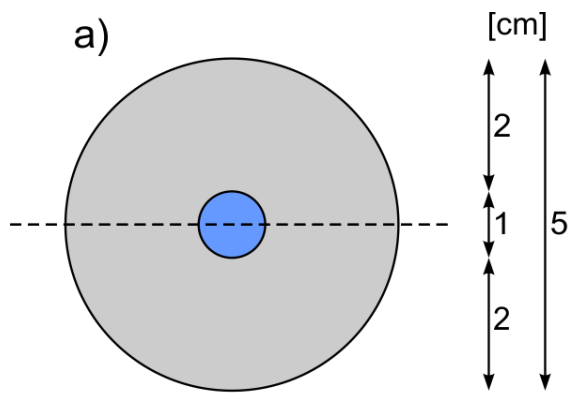

b)

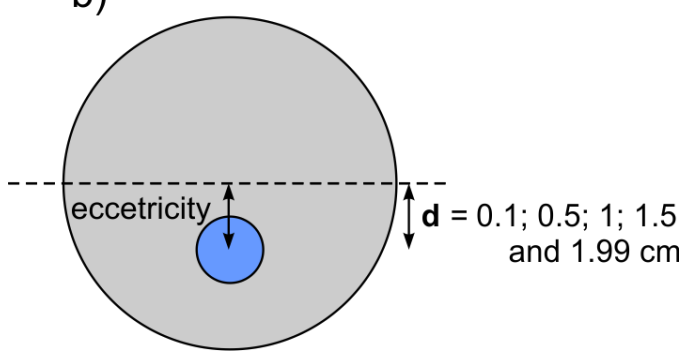

Fig. 1. Model of bar embedded in concrete cover a) without geometric imperfections and b) with variable eccentricity of the inside steel rod

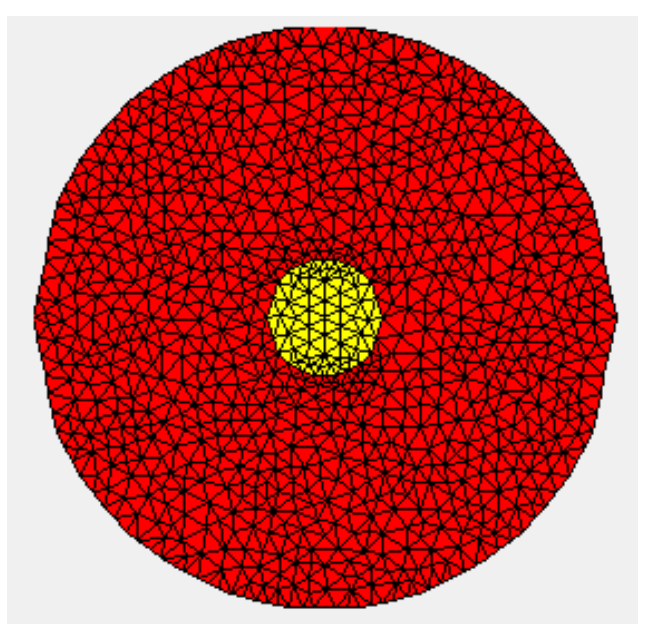

Fig. 2. Discretized cross section of two-layer cylindrical bar (yellow - steel; red - mortar) 


\section{DISPERSION CURVES}

In general, guided waves are dispersive which means that their velocity depends on excitation frequency. The relation between frequency and group velocity is usually presented in the form of dispersion curves. Determining the shape of the dispersion curves for the investigated cross-section is crucial aspect, necessary in subsequent stages of the nondestructive monitoring process. Tracing dispersion curves requires solution of dispersion equation. In the case of multilayered systems stresses and displacements can be expressed in the terms of amplitudes of partial waves existing in each layer. The assumption about the continuity of stresses and displacements at the common boundaries lead to global matrix equation:

$$
\mathbf{G A}=0
$$

a)

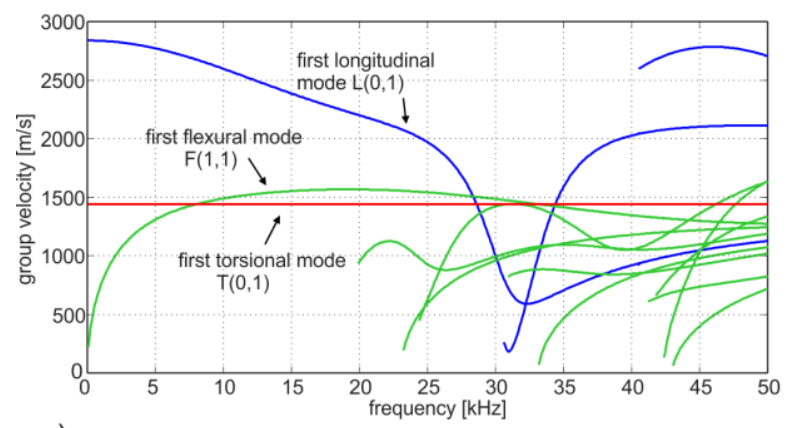

c)

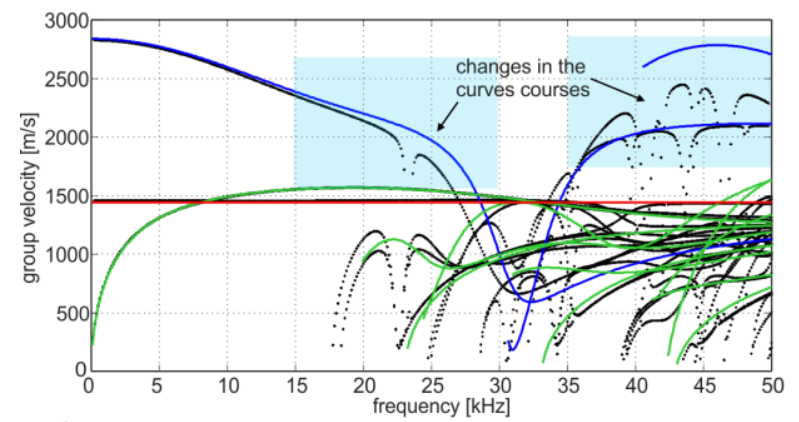

e)

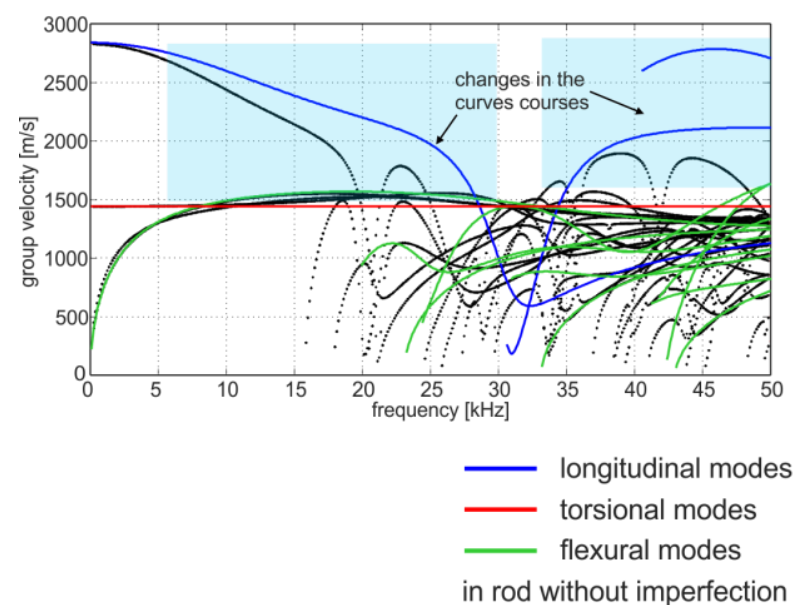

where $\mathbf{G}$ is global matrix and $\mathbf{A}$ is vector of partial wave amplitudes. Nontrivial solution of partial wave amplitudes vector $\mathbf{A}$ can be obtained when the following condition is satisfied:

$$
\operatorname{det} \mathbf{G}=0
$$

Equation (2) is characteristic equation and its roots give dispersion curves. The full derivation of dispersion equation for multilayered systems is well documented in literature e.g. [12],[21],[22]. However, analytical solution can be formulated only for flat or cylindrical, axisymmetric layers. For more complex cross sections it is necessary to use numerical approach e.g. semi-analytical finite element method (SAFE) [23], wave finite element method (WFE) [24] or scale-boundary finite element method (SBFE) [25] to obtain dispersion curves.

b)

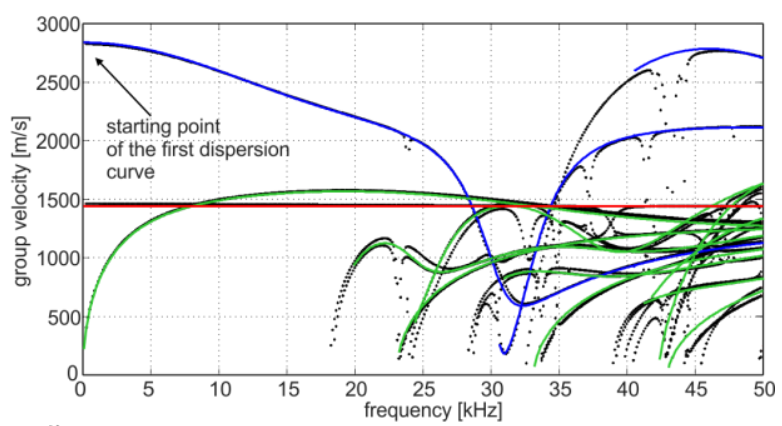

d)

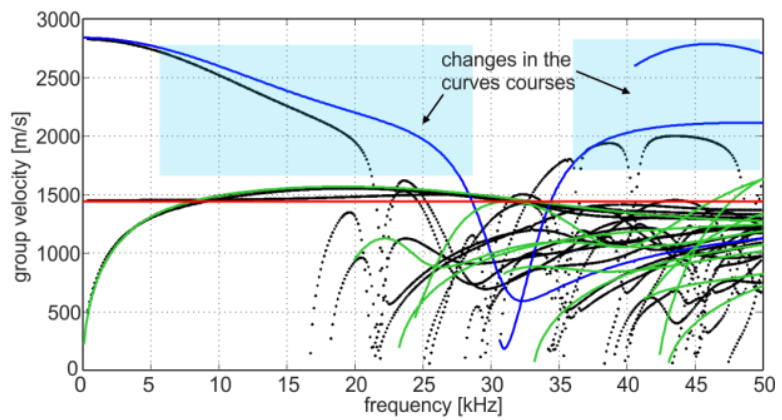

f)

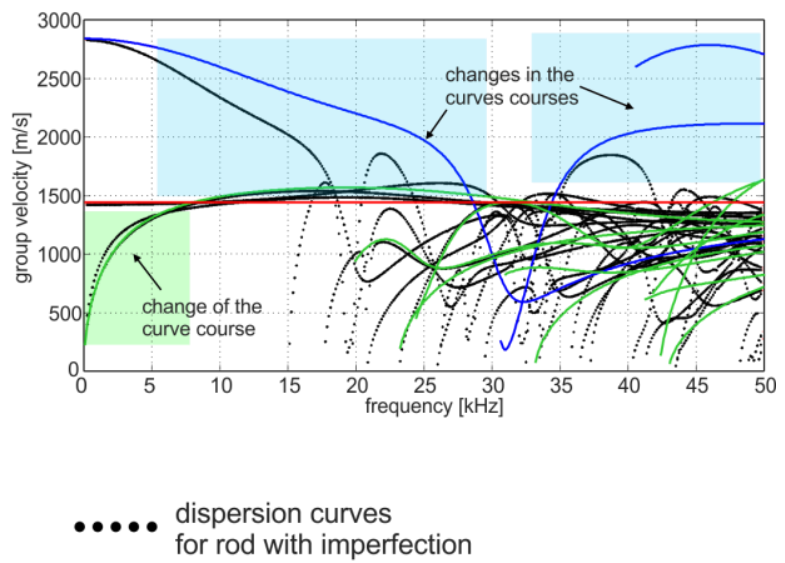

Fig. 3. Dispersion curves for bar embedded in concrete cover a) without geometric imperfections and with eccentricity equals to b) $1 \mathrm{~mm}$, c) $5 \mathrm{~mm}$, d) $10 \mathrm{~mm}$, e) $15 \mathrm{~mm}$, f) $19.9 \mathrm{~mm}$ 
Figure 3 presents the dispersion curves for healthy covered bar and bars with deviation from axial symmetry obtained using software GUIGUW and PCDISP. Out of consideration for readability dispersion curves were determined in limited frequency range $0-50 \mathrm{kHz}$. From the practical point of view, waves are usually excited in embedded metal waveguide and then are transmitted into surrounding medium [26]. In the case of eccentric location, waves are also excited non-centrally, what leads to excitation not only longitudinal modes, but also flexural modes. For this reason, all modes families, flexural, longitudinal and also torsional are considered here. Colored lines are dispersion curves for rod without eccentricity, while dispersion curves for imperfect rods are marked by black color. It can be seen that eccentric location of the steel waveguide affects dispersion solution. The influence of geometric imperfection is the most significant in the case of longitudinal modes. For the rod with relatively small imperfection (eccentricity equals to $1 \mathrm{~mm}$ what is $2 \%$ of the diameter or the rod - Fig. 1b) changes in waves velocity can be neglected but with the increasing of eccentricity the differences between dispersion curves are more and more significant.

In general, wave velocity decreases with the imperfection size in the entire analyzed frequency range. Since wave propagation velocity is usually a key parameter in diagnostics process, changes in wave velocities may lead to inaccurate estimation of those quantities that can be determined on the basis of time-of-flight (ToF) during nondestructive evaluation of two-layer rods i.e. bonding length or debonding length [19],[26]. To minimize the influence of eccentricity on the obtained results one can choose frequency which is insensitive to this kind of imperfections. In the case of longitudinal modes one can see that starting point of the first dispersion curve remains stationary regardless of the level of the damage (Fig. 3b). Then, choosing relatively low frequencies in practice allows to omit the influence of the waveguide eccentricity on registered signals.

Torsional and flexural modes proved to be less sensitive to the eccentricity of covered waveguide than longitudinal modes. Some differences in curves course for variable damage level seem to be negligible. In the case of first flexural mode, changes in dispersion curve course are found only for the extreme case of waveguide location (Fig. 1b) when the minimal thickness of the cover was equal to $1 \mathrm{~mm}$ (Fig. 3f). For the other flexural modes changes in velocities are apparent, however they are not as clear as in the case of longitudinal modes.

The torsional mode turned out to be the least sensitive to waveguide eccentricity. However, its application in the diagnostic process is difficult because of technical problems with an excitation, especially in specimens of big sizes.

\section{NUMERICAL INVESTIGATIONS}

\subsection{Numerical model}

Numerical calculations were performed by means of commercial programme Abaqus/Explicit based on Finite Element Method. Eight-node brick finite elements with reduced integration (C3D8R) were applied here. The analysis was conducted for a $1 \mathrm{~cm}$ diameter steel rod embedded in mortar cover with a thickness equal to $2 \mathrm{~cm}$. The same material parameters were adopted as in the case of the analytical model: for steel $E=210 \mathrm{GPa}, v=0.3, \rho=$ $7850 \mathrm{~kg} / \mathrm{m}^{3}$ and for the mortar $E=10 \mathrm{GPa}, v=0.2$, $\rho=2000 \mathrm{~kg} / \mathrm{m}^{3}$. The length of the specimen was equal to $0.5 \mathrm{~m}$.

Three different models were investigated numerically: rod without geometric imperfections (model \#1), model with off-center position of steel core and eccentricity equal to $10 \mathrm{~mm}$ (model \#2) and eccentricity equal to $19.9 \mathrm{~mm}$ (model \#3).

Waves were excited and registered at the middle point of the steel rod, in the longitudinal and perpendicular directions. It results in excitation of both longitudinal and flexural modes. Wave excitation and signal registration were realized at the opposite ends of specimen.

The wave packet consisted of ten-cycle sine with a carrier frequency equal to $50 \mathrm{kHz}$ modulated by the Hanning window. The excitation frequency was chosen because of its sensitivity to eccentricity of the steel core (see Fig. 3). The maximum element size $\left(1 \times 1 \times 1 \mathrm{~mm}^{3}\right)$ and the time integration step $\left(10^{-7} \mathrm{~s}\right)$ were established on the basis on the wavelength and wave velocity.

\subsection{Numerical results}

Results of numerical calculations are presented in the form of the displacements and accelerations maps and wave propagation signals registered at the end of specimen.

Figure 4 presents the comparison of snapshots of propagating wave for three different cases for the selected time instants. The first column contains snapshots for model \#1, the second for model \#2 and the third for model \#3. Wave is excited in metal core, so for rods with an artificial eccentricity disturbance starts propagating closer to the specimen edge $(t=0.02 \mathrm{~ms})$. In the case of perfect specimen deformation caused by disturbance travelling is axisymmetric (model $\# 1$ - case $a, t=0.1$ $\mathrm{ms}$ ), while for the other two models immediately after the wave is excited, a distinct asymmetry of deformation is visible (cases $b$ and $c$ for $t=0.01 \mathrm{~ms}$ and $t=0.016 \mathrm{~ms}$ ). The violating of axial symmetry of propagating deformation is definitely more visible in the case of the greater geometric imperfection.

The results in the form of maps allow to observe that wave velocity differs for particular models. 
a)

$\mathrm{t}=0.02 \mathrm{~ms}$

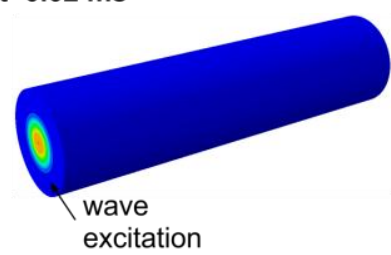

$\mathrm{t}=0.1 \mathrm{~ms}$

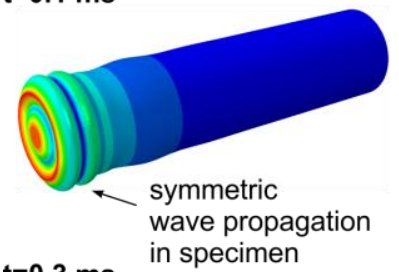

$\mathrm{t}=0.3 \mathrm{~ms}$

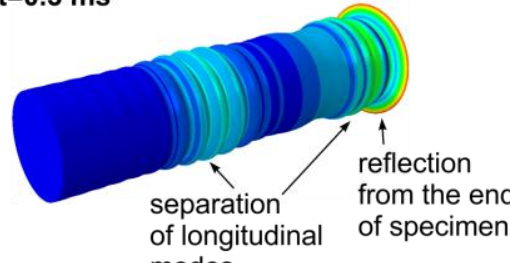
modes

$\mathrm{t}=\mathbf{0 . 4 2} \mathrm{ms}$

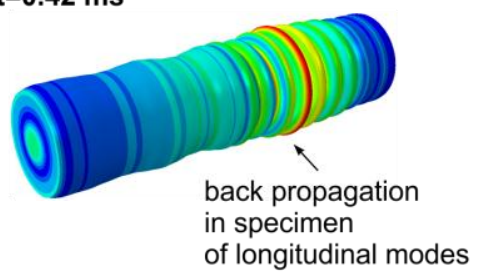

b)

$\mathrm{t}=0.02 \mathrm{~ms}$

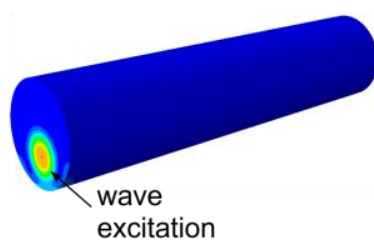

$\mathrm{t}=0.1 \mathrm{~ms}$

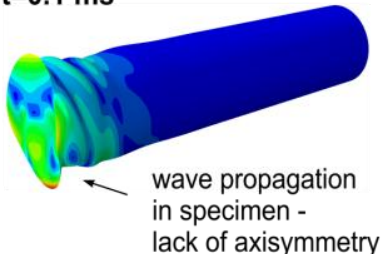

$\mathrm{t}=0.52 \mathrm{~ms}$

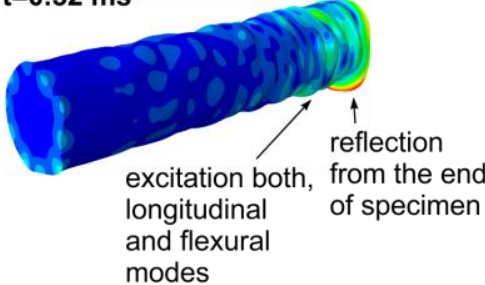

$\mathrm{t}=\mathbf{0 . 7 6} \mathrm{ms}$

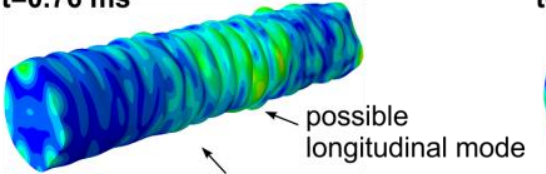

back propagation

in specimen

of longitudinal and flexural modes c)

$\mathrm{t}=0.02 \mathrm{~ms}$

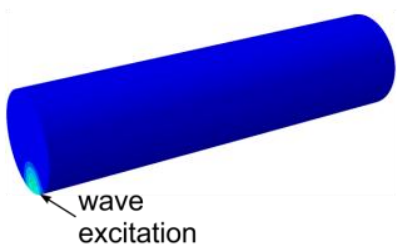

$\mathrm{t}=0.16 \mathrm{~ms}$

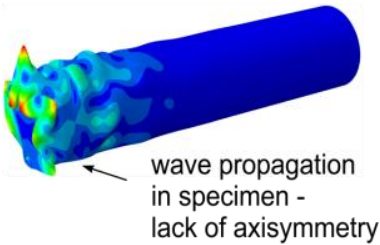

$\mathrm{t}=0.52 \mathrm{~ms}$

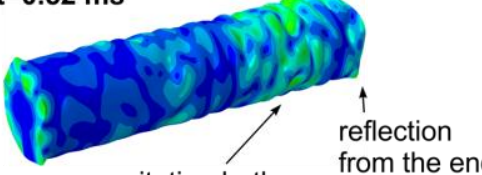

excitation both, from the en longitudinal and flexural modes

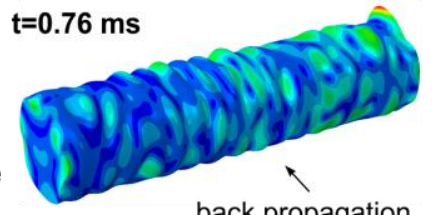

back propagation

in specimen

of longitudinal and flexural modes

Fig. 4. FEM results of wave propagation in embedded waveguide for selected time instants: a) model \#1 without geometric imperfection; b) model \#2 with eccentricity of $10 \mathrm{~mm}$ and c) model \#3 with eccentricity of $19.9 \mathrm{~mm}$

a)

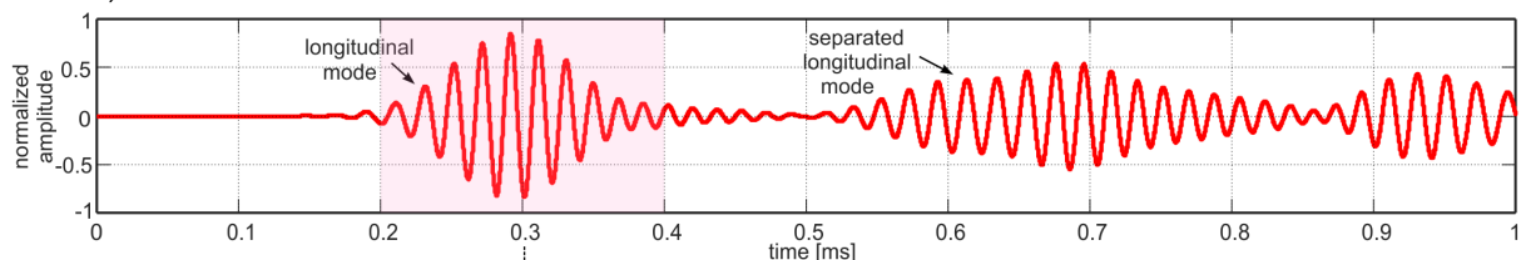

b)

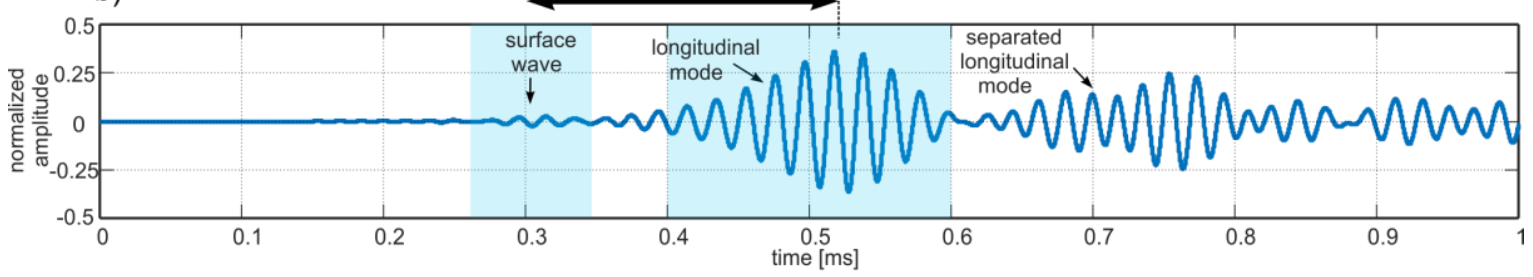

c)

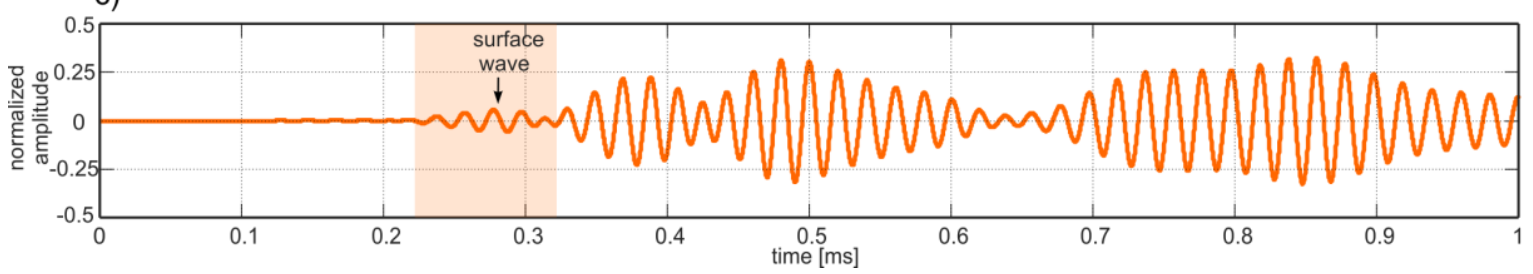

Fig. 5. Numerical time-domain acceleration signals registered at the end of: a) model \#1 without geometric imperfection; b) model \#2 with eccentricity of $10 \mathrm{~mm}$ and c) model \#3 with eccentricity of $19.9 \mathrm{~mm}$ for longitudinal excitation 
a)

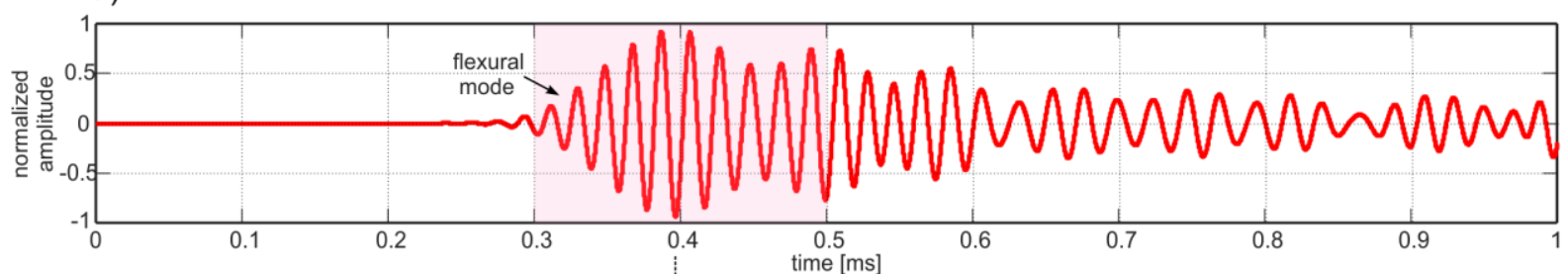

b)
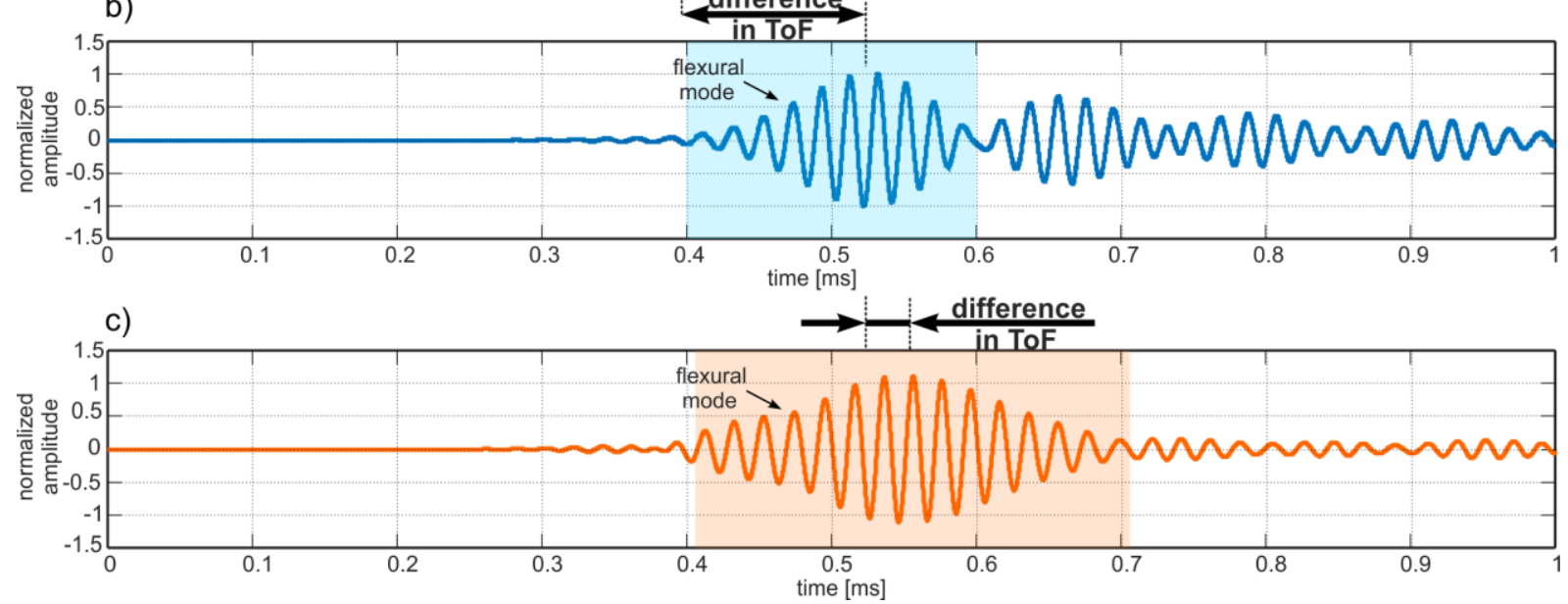

Fig. 6. Numerical time-domain acceleration signals registered at the end of: a) model \#1 without geometric imperfection; b) model \#2 with eccentricity of $10 \mathrm{~mm}$ and c) model \#3 with eccentricity of $19.9 \mathrm{~mm}$ for flexural excitation

The reflection from the end of specimen is registered at $t=0.3 \mathrm{~ms}$ for model $\# 1$ (Fig. $4 \mathrm{a}$ ), while for the other two cases wave reflects later but the difference in their time-of-flight is not considerable. Then, one can conclude that wave velocity is lower for rods with eccentricity what is consistent with the results of the theoretical analysis and the course of dispersion curves (compare Fig. 3).

Another difference between rods with and without imperfection is the clarity of the separated modes. In the case of the undamaged, axisymmetric rod two longitudinal modes can be easily indicated, the faster one is characterized by higher amplitude (Fig. 4, case $a, t=0.3 \mathrm{~ms}$ ). For the model \#2 and \#3 it is difficult to unambiguously indicate particular wave modes. As a result, the phenomenon is more difficult to interpret.

Figure 5 and 6 presents results in the form of time-domain signals for variable level of deviation from axial symmetry. Figure 5 contains the results for the longitudinal excitation while Fig. 6 concerns perpendicular excitation.

In both cases first reflection from the end of the specimen is registered in different times for perfect and imperfect rods. As was proved in papers [19],[20] and [26] when for the analyzed excitation frequency more than one wave mode can propagate, mode with the highest velocity is registered first. Usually, from the point of view of the diagnostic procedure, this reflection is the most important as reflection which is characterized by the high amplitude and is the easy to identify. Rod eccentricity influences on dispersion curves courses and in consequences changes the time-of-flight of particular reflections. The presence of eccentricity of steel waveguide may lead to inappropriate estimation of the wave velocity which in turn may result in incorrect determination of e.g. geometric parameters.

However, on the basis of dispersion curves steady velocity decrease of the longitudinal wave is expected, meanwhile disturbance caused by wave motion is registered earlier for the rod with imperfection of $19.9 \mathrm{~mm}$ than for imperfection of $10 \mathrm{~mm}$ (compare Fig. 5b and 5c). A possible explanation of this fact may be the surface wave propagation. (Fig. 7). As the imperfection decreases, wave is excited closer to the outer surface what leads to inducing not only flexural and longitudinal modes, but also Rayleigh wave. Rayleigh wave characterized by high wave velocity is not taken into account in the dispersion solution (Fig. 3). In previously mentioned papers [26] it was proved that surface wave propagation can be effectively used in a dimension estimation e.g. thickness of the cover of a partially embedded bar, but in some cases also it can strongly affect the time-domain signals and consequently, prevent their use in the diagnostic procedure.

Surface wave propagating in the model with imperfection of $19.9 \mathrm{~mm}$ was identified in Fig. 7. Particular amplitude changes indicative of Rayleigh wave propagation after the longitudinal excitation were identified and marked in signals in Fig. 5. 


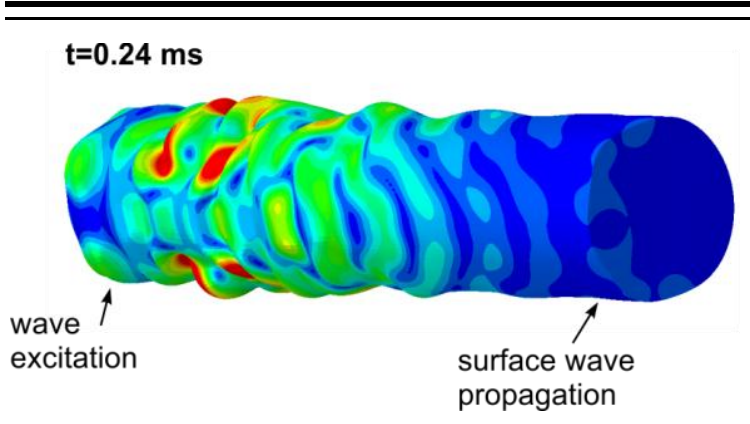

Fig. 7. Surface wave propagation in embedded waveguide with eccentricity of 19.9 mm (model \#3)

The results in the form of signals for the flexural wave propagation are presented in Fig. 6. For the subsequent bars the first peak are registered later, so the velocity of the fastest flexural mode decreased. The difference in velocities is less significant than for the longitudinal modes because of lower sensitivity to this type of imperfections. Additionally, for the flexural time-domain signals it is difficult to isolate the wave package representing surface wave propagation.

Waveguide eccentricity has an impact not only on wave velocity but also on the signal amplitude and shape. Despite applying the identical load in numerical model, signal amplitude decreased with an eccentricity for the longitudinal excitation and increased for the flexural excitation. Therefore, the presence of imperfection may require the use of high-energy excitation, which is a particular problem in the case of non-destructive testing of large sized objects.

\section{CONCLUSIONS}

The paper presents results of numerical and analytical investigation in the field of wave propagation in embedded specimen with artificially introduced geometric imperfection in the form of off-center position of the steel waveguide. First, the influence of variable level of geometric imperfection is analysed by comparing course of the dispersion curves. Next, numerically obtained deformations caused by wave motion and timedomain signals are compared.

Both, the dispersion curves and the results of numerical calculations for variable imperfection allowed to observe the impact of imperfection size on wave propagation velocity. Larger changes in wave velocity were noted for the longitudinal than the flexural modes due to their different sensitivity to damages in the form of eccentricities.

The off-center position of embedded waveguide has also influence on shape and amplitude of recorded signals. Due to the fact that wave velocity and signal amplitude are often key parameters used in the diagnostic process that allow to determine e.g. geometric parameters or quality of adhesive bonding between layers, not taking into account the possibility of geometrical imperfection may lead to significant disturbance in the results interpretation.

\section{ACKNOWLEDGMENTS}

Abaqus computations were carried out at the Academic Computer Centre in Gdańsk.

\section{REFERENCES}

1. Firestone FA, Ling DS Jr. Method and means for generating and utilizing vibrational waves in plates, US Patent 2,536,126, 1951.

2. Palacz M, Krawczuk M, Ostachowicz W. Detection of additional mass in rods: Experimental and numerical investigation, Archives of Applied Mechanics, 2005;74(11-12):820-826. https://doi.org/10.1007/s00419-005-0395-4

3. Lucena RL, Dos Santos JMC. Structural health monitoring using time reversal and cracked rod spectral element, Mechanical Systems and Signal Processing, 2016;79:86-98.

https://doi.org/10.1016/j.ymssp.2016.02.044

4. Tse P, Wang X. Semi-quantitative analysis of defect in pipelines through the use of technique of ultrasonic guided waves, Key Engineering Materials, 2009;413414:109-116. 10.4028/www.scientific.net/KEM.413$\underline{414.109}$

5. Sanderson RM, Hutchins DA, Billson DR, Mudge PJ. The investigation of guided wave propagation around a pipe bend using an analytical modelling approach, The Journal Acoustical Society of America, 133(3), 1404-1414, 2013. https://doi.org/10.1121/1.4790349

6. Lowe MJS. Alleyne DN, Cawley P. Defect detection in pipes using guided waves, Ultrasonics, 36, 147 154, 1998. https://doi.org/10.1016/S0041624X(97)00038-3

7. Zumpano G, Meo M. A new damage detection technique based on wave propagation for rails, International Journal of Solids and Structures, 2006;43(5):1023-1046. https://doi.org/10.1016/j.ijsolstr.2005.05.006

8. Mariani S, Nguyen T, Phillips RR, Kijanka P, Lanza di Scalea F, Staszewski WJ, Fateh M, Carr G. Noncontact ultrasonic guided wave inspection of rails, Structural Health Monitoring, 2013;12(5-6): 539-548. https://doi.org/10.1177/1475921713498533

9. Armenákas AE. Propagation of harmonic waves in composite circular-cylindrical rods. The Journal of Acoustical Society of America 1970; 47: 822-837. https://doi.org/10.1121/1.1911965

10. Baltrukonis JH, Gottenberg WG, Schreiner RN. Axial-shear vibrations of an infinitely-long composite circular cylinder. The Journal of Acoustical Society of America 1961; 33(11): 1447-1457. https://doi.org/10.1121/1.1908468

11. Thurston RN. Elastic waves in rods and clad rods. The Journal of Acoustical Society of America 1978; 64(1): 1-37. https://doi.org/10.1121/1.381962

12. Pavlakovic BN. Leaky guided ultrasonic waves in NDT. PhD thesis, Imperial College of Science, Technology and Medicine, 1998. https://doi.org/10.1111/mice.12129

13. Beard MD, Lowe MJS, Cawley P. Ultrasonic Guided Waves for Inspection of Grouted Tendons and Bolts. Journal of Materials in Civil Engineering 2003; 15(3): 212-218. 
https://doi.org/10.1061/(ASCE)08991561(2003)15:3(212)

14. Beard MD, Lowe MJS. Non-destructive testing of rock bolts using guided ultrasonic waves. International Journal of Rock Mechanics and Mining Sciences 2003; 40(4): 527-536. https://doi.org/10.1016/S1365-1609(03)00027-3

15. Zou DH, Cheng J, Yue R, Sun X. Grout quality and its impact on guided ultrasonic waves in grouted rock bolts. Journal of Applied Geophysics 2010; 72(2): 102-106.

https://doi.org/10.1016/j.jappgeo.2010.07.006

16. Madenga V, Zou DH, Zhang C. Effects of curing time and frequency on ultrasonic wave velocity in grouted rock bolts. Journal of Applied Geophysics 2006; 59(1): 79-87.

https://doi.org/10.1016/j.jappgeo.2005.08.001

17. Zou DH, Cui Y, Madenga V, Zhang C. Effects of frequency and grouted length on the behaviour of guided ultrasonic waves in rock bolts. International journal of Rock mechanics and Mining Sciences 2007; 44(6): 813-819. https://doi.org/10.1016/j.ijrmms.2006.12.002

18. Cui Y, Zou DH. Assessing the effect of insufficient rebar and missing grout in grouted rock bolts using guided ultrasonic waves. Journal of Applied Geophysics 2012; 79: 64-70. https://doi.org/10.1016/j.jappgeo.2011.12.010

19. Zima B, Rucka M. Guided ultrasonic waves for detection of debonding in bars partially embedded in grout. Construction and Building Materials 2018; 168: $124-142$. https://doi.org/10.1016/j.conbuildmat.2018.02.107

20. Zima B, Rucka M. Detection of debonding in steel bars embedded in concrete using guided wave propagation. Diagnostyka 2016; 17(3): 27-34.

21. Knopoff L. A matrix method for elastic wave problems. Bulletin of Seisomological Society of America 1964; 54(1): 431-438.

22. Randall MJ. Fast programs for layered half-spaced problems. Bulletin of Seismological Society of America, 1967; 57(6): 1299-1316.

23. Treyssède F. Numerical investigation of elastic modes of propagation in helical waveguides. Journal of Acoustic Society of America 2007; 121(6): 33983408. https://doi.org/10.1121/1.2730741

24. Søe-Knudsen A, Sorokin S. On accuracy of the wave finite element predictions of wavenumbers and power flow: a benchmark problem. Journal of Sound and Vibration 2011; 330(12): 2694-2700. https://doi.org/10.1016/j.jsv.2011.02.022

25. Liu YJ, Han Q, Li CL, Huang HW. Numerical investigation of dispersion relations for helical waveguides using the scaled boundary finite element method. Journal of Sound and Vibration 2014; 333(7): 1991-2002.

https://doi.org/10.1016/j.jsv.2013.11.041

26. Zima B, Rucka M. Non-destructive inspection of ground anchors using guided wave propagation. International Journal of Rock Mechanics and Mining Sciences 2017; 4(1): 90-102.

https://doi.org/10.1016/j.ijrmms.2017.03.005

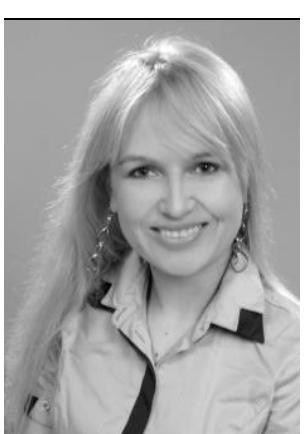

Beata ZIMA, Ph.D. graduated civil engineering at the Faculty of Civil and Environmental Engineering, Gdansk University of Technology. She mainly deals with diagnostics of structural elements using guided wave propagation.

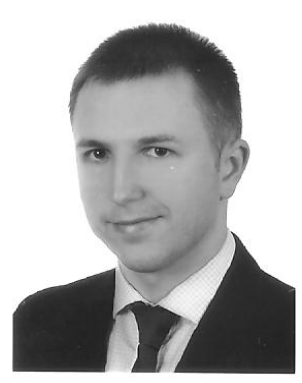

Rafał KĘDRA, M.Sc. graduated civil engineering at Gdańsk University of Technology. Since October 2014 he continues his education as a Ph.D. student. His main interests are modelling of mechanical structures and non-destructive testing. 